
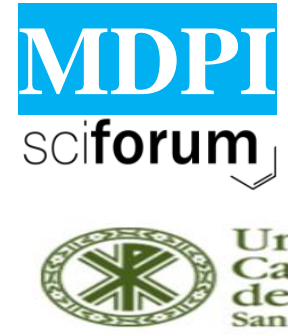

Universidad

Católica

de Valencia

* > International > About us

International
IWIMSM-03: Iberoamerican Workshop on

Model. and Simulation Methods, Valencia, Spain, 2019

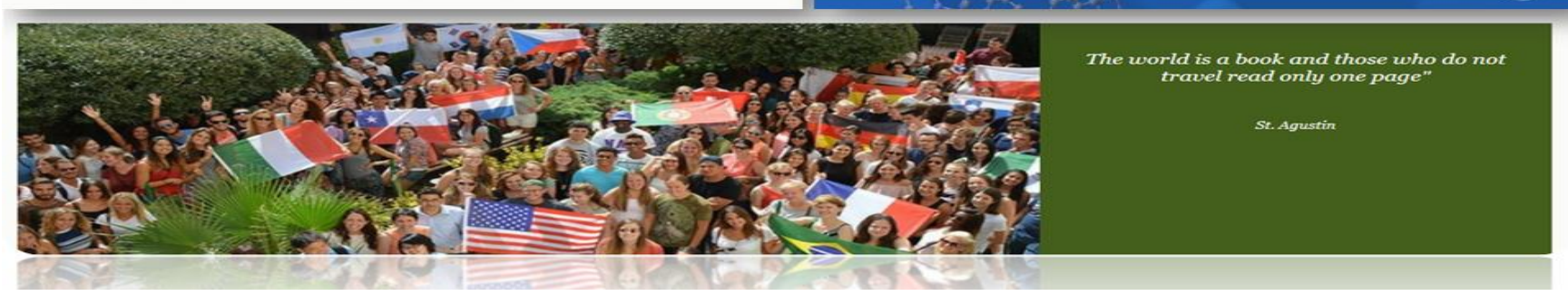

\title{
Preliminary study on the existence of ocular injuries after bullfighting or fire bull
}

Carla Ibáñez. Sanchis (carla.ibanez@ucv.es) ${ }^{a}$, Daphne Ferreres Fuster ${ }^{a}$, Javier Mazón Marín $^{a}$.

${ }^{a}$ Animal Production and Public Health Department. Catholic University of Valencia

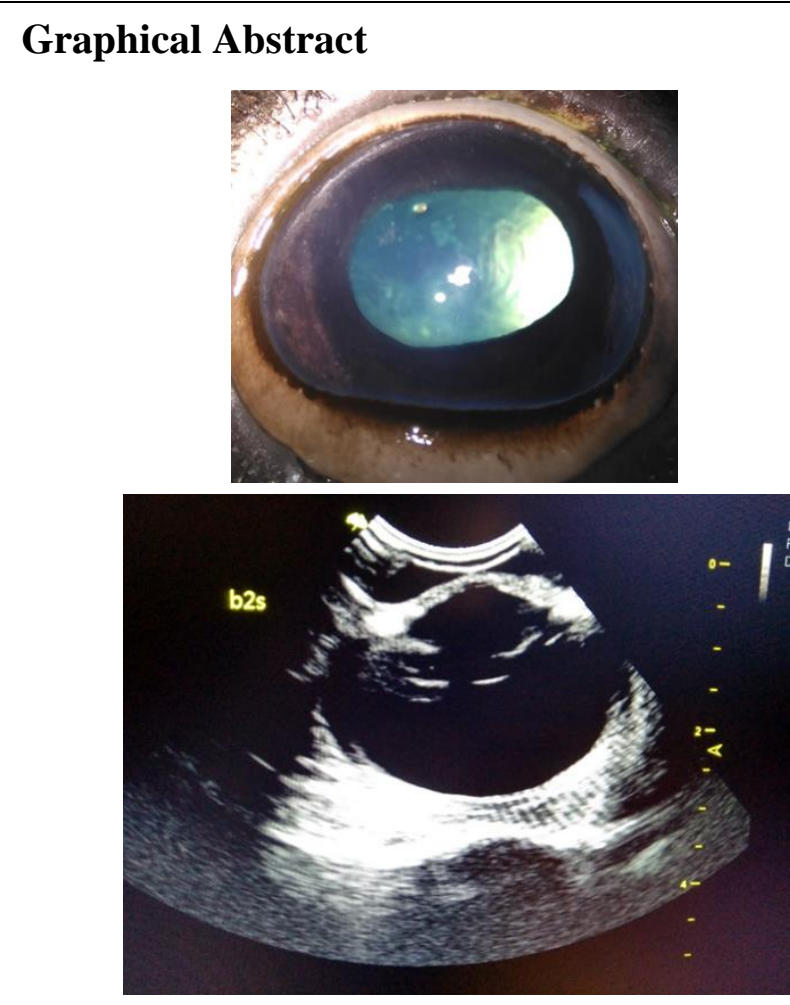

\section{Abstract.}

The vision of the bull is the cornerstone of the celebration in which it is the protagonist, both when it is fought and when it is "embolado" in popular festivities. An alteration of the vision could suppose an excessive danger for the animal and for the one that faces him. The bullfight and the fire bull are traditions that present controversy between certain groups of people, for that reason, the present study aims to determine if there are ocular injuries in the bulls after both activities.

For this work we use a total of 50 eyes, 40 from 20 fighting bull and 10 from 5 fire bulls. After the macroscopic and microscopic study carried out with fluorescein tests, ultrasounds, dissection and histological processing of all the samples, the 


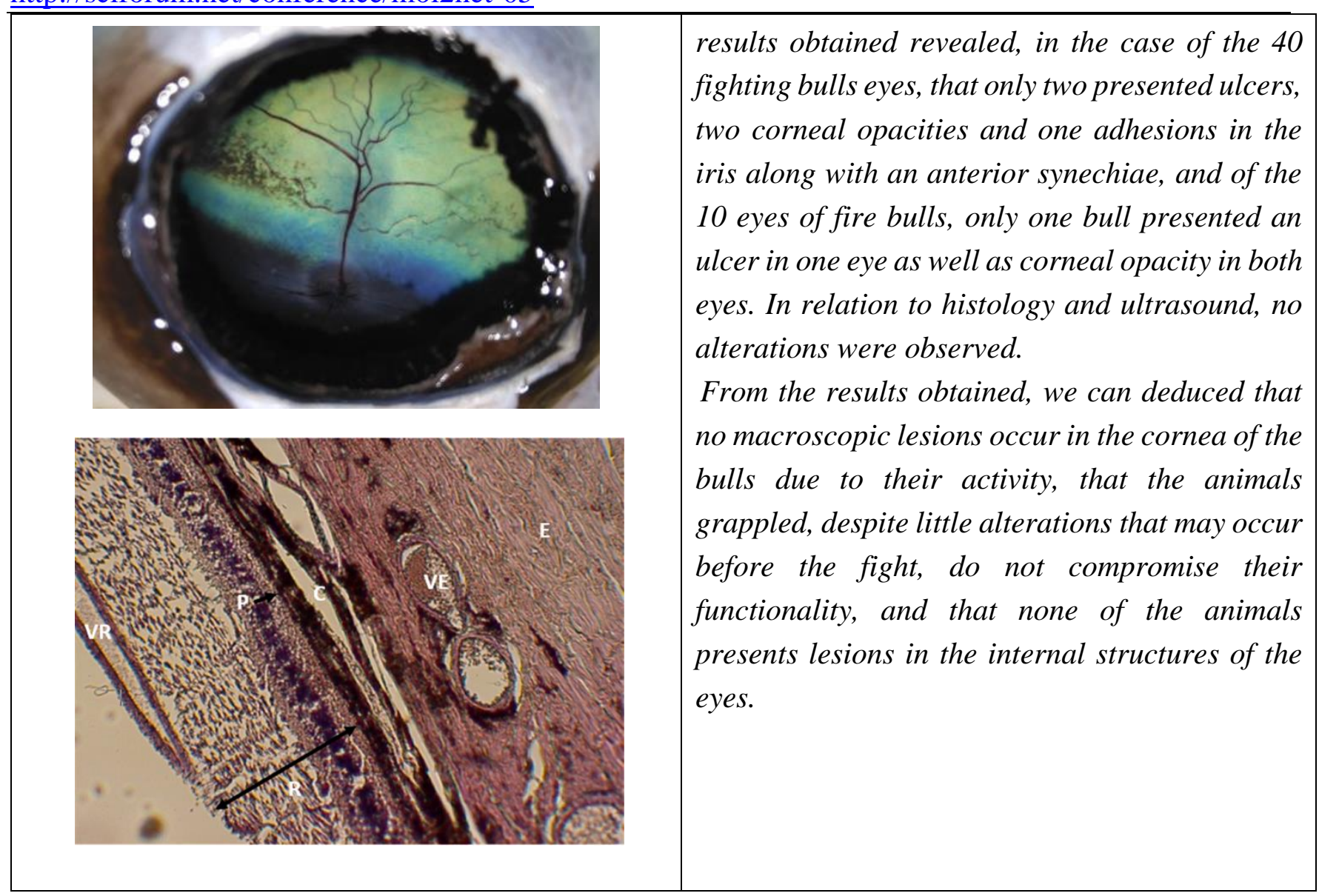

\section{Introduction}

The present work seeks to deepen the vision of the fighting bull and assess the possible injuries that may occur during the bull fighting or in the popular celebration of fire bull. The objectives set are the following:

- Determine if there are macroscopic or microscopic ocular lesions after bull fighting.

- Determine if there are macroscopic or microscopic ocular lesions after putting the fire on the bull's horns.

\section{Materials and Methods}

The fighting bull eye samples were obtained during March 2018 at the bullring of Valencia. A total of 40 eyes were obtained from 20 bulls, whose ages were between 4 and 5 years, from ten different livestock farms, belonging to the Union of Breeders of Fighting Bull and only one of them to the Spanish Association of Cattle Ranchers. There were several "encastes", predominantly Domecq.

The samples of fire bull eyes were taken after slaughter of the animals in a slaughterhouse of the Valencian Community between the months of September to November 2018. These are animals raised in native livestock, whose ages are between 6 and 10 years and with 8 and 11 number of "emboladas" per animal. Due to the difficulty in obtaining these samples, because of the low number of animals slaughtered with these characteristics annually and the reluctance of some farmers to grant us permission, samples of only 5 bulls were obtained, therefore, a total of 10 eyes from fire bulls.

Sample collection

As an initial step and to preserve the identity of the bull participating in the study, an internal code was granted for the identification of each sample obtained. 
Before removal the eyeball from the orbital fossa, a visual examination was performed to detect possible macroscopic alterations, especially in the case of fighting bull where lesions may appear due to drag. The extraction of the eyeball was performed with the eyelids, immediately after slaughter, in the bullring or in the slaughterhouse, using scalpel and Adson tweezers with special precaution to avoid damaging any ocular structure. Samples were stored in serum to prevent corneal damage until dissection and transferred to the Veterinary Hospital of the Catholic University of Valencia San Vicente Mártir.

Macroscopic study

First, the fluorescein test was performed on all samples. This test is intended to examine the corneal surface, because fluorescein has an affinity for water and stains the stroma of the cornea yellowish when it is not covered by epithelium, showing ulcers or lesions, when eyes are illuminated with a blue light source.

Subsequently, using the mode B ultrasound, the different anatomical regions of the eye were identified, before beginning the dissection of the eye, in order to verify the existence of intraocular alterations.

Finally, and after different attempts to study the retina through non-invasive methods such as the use of a retinoscope, it was necessary to address the dissection of the eye and remove the lens, leaving the vitreous humor intact. Being able to observe, in this way, the fundus of the eye, the retina, the optic disc and the blood vessels.

Microscopic study

In the present work a microscopic study of the retina of the bull has been carried out. To be able to observe the different tissues in the microscope, the preparation of histological cuts and the stain of the samples with Hematoxylin-Eosin were necessary.

\section{Results and Discussion}

Ocular alterations found in the study.

\begin{tabular}{|c|c|c|c|c|c|c|c|}
\hline & \multirow[b]{2}{*}{ Sample } & \multicolumn{3}{|c|}{ OS } & \multicolumn{3}{|c|}{ OD } \\
\hline & & $\begin{array}{c}\text { Previous visual } \\
\text { examination }\end{array}$ & Fluorescein & Others & $\begin{array}{c}\text { Previous visual } \\
\text { examination }\end{array}$ & Fluorescein & Others \\
\hline \multirow{20}{*}{ Fighting bull } & $\mathrm{Z1}$ & & 0 & & & 0 & \\
\hline & Z1 & & 0 & & & 0 & \\
\hline & $\mathrm{X} 1$ & & 0 & & & 0 & \\
\hline & $\mathrm{X} 2$ & & 0 & & & 0 & \\
\hline & W1 & & 0 & & & 0 & \\
\hline & W2 & & 0 & & & 0 & \\
\hline & U1 & & 0 & & & 0 & \\
\hline & $\mathrm{U} 2$ & & 2 & & & 0 & \\
\hline & $\mathrm{T} 1$ & & 0 & & & 0 & \\
\hline & $\mathrm{T} 2$ & & 0 & & & 0 & \\
\hline & S1 & & 0 & & & 0 & \\
\hline & S2 & & 0 & & & 1 & \\
\hline & $\mathrm{R} 1$ & & 0 & & & 0 & \\
\hline & $\mathrm{R} 2$ & & 0 & & & 0 & \\
\hline & P1 & & 0 & & & 0 & \\
\hline & P2 & & 0 & & & 0 & \\
\hline & N1 & & 0 & & & 0 & \\
\hline & $\mathrm{N} 2$ & $\mathrm{OC}$ & 0 & $\mathrm{AI}+\mathrm{SIC}$ & & 0 & \\
\hline & L1 & & 0 & & & 0 & \\
\hline & $\mathrm{L} 2$ & $\mathrm{OC}$ & 0 & & & 0 & \\
\hline \multirow{5}{*}{ Fire bull } & A1 & & 0 & & & 0 & \\
\hline & $\mathrm{A} 2$ & $\mathrm{OC}$ & 1 & & $\mathrm{OC}$ & 0 & \\
\hline & $\mathrm{A} 3$ & & 0 & & & 0 & \\
\hline & B1 & & 0 & & & 0 & \\
\hline & B2 & & 0 & & & 0 & \\
\hline \multicolumn{2}{|c|}{ Total eyes } & \multicolumn{3}{|c|}{25} & \multicolumn{3}{|c|}{25} \\
\hline
\end{tabular}

OS: Left eye, OD: Right eye, OC: Corneal opacity, AI: Adherence of the iris, SIC: Synechiae between iris and cornea. 
Prevalence of eye disorders.

\begin{tabular}{|c|c|c|c|}
\hline Alteration & Fighting bull (40 eyes) & Fire bull (10 eyes) & Results \\
\hline Corneal opacity & 2 & 2 & $8 \%$ \\
\hline Fluorescein & 2 & 1 & $6 \%$ \\
\hline Synechiae & 1 & 0 & $2 \%$ \\
\hline Ultrasound & 0 & 0 & $0 \%$ \\
\hline Histology & 0 & 0 & $0 \%$ \\
\hline
\end{tabular}

According to the study of the cornea, the most superficial layer of the eye and therefore more susceptible to injury, the results reveal that of the 50 samples analyzed 4 presented corneal opacity, 3 ulcers and 1 presented an adhesion between the upper and lower part of the iris along with a previous synechiae.

In relation to corneal opacity, it is probably that there were old lesions that animals presented before the activity in question. Maybe veterinarians didn't see the corneal opacity in their examination before the activity, because animals respond to visual stimuli correctly and a proximity test cannot be carried out. In relation to the ulcers, given the small size of them, we can estimate that, in the case of the fighting bull, these were possibly caused by the drag after the fight, being the sand of the square the cause of this laceration. Regarding the injury of the fire bull, based on the work done by Martínez P. et al. in 2017, and despite the small sample size, the small ulcer found in one of the eyes of the five animals is more likely to be associated with trauma during the festivities or in the livestock facilities, even due to fights between animals, than with the effects of fire during the celebration. We must bear in mind that these are animals that have been "embolados" between 8 and 11 times throughout their life, so the repetitiveness of this activity, if it was the cause, it should lead to a greater presence both in the number of ulcers as in the number of animals affected.

Related to the adhesion between both parts of the iris, there are different reasons why it can occur. The first of these is the persistence of the pupillary membrane, because no adhesions of the iris to the cornea or the lens were observed. It is a congenital defect frequently diagnosed in small animals. This occurs when there is an alteration in the mesodermal development whereby the normal regression of the pupillary membrane stops at some point, persisting mesodermal elements that can cause permanent defects in the cornea, iris or lens. Another reason is the polycoria, a condition in which there is more than one pupil, can be caused by hypoplasia or hyperplasia of the iris stroma. The third, as a result of trauma, something not negligible in this species. In relation to previous synechiae, these may be of congenital origin or caused by trauma.

The ultrasound images show no evidence of alteration of any of the anatomical structures identified. The anterior and posterior capsule of the lens appear intact, as well as its location in physiological place and position in all cases. No changes are observed in the retina, coinciding with the study conducted by Maghraby H. et al. in the eye of the bovine. Therefore, we can estimate that the animal does not suffer ocular alterations, such as retinal detachments or lens dislocations, during either of the two celebrations, despite being able to suffer some trauma when they are dressed against the barrier or the chopping horse in the square or against the "cadafals" in the popular celebrations.

The retina is the place of the eye where perceived images are projected and one of the deepest layers; this makes it an indispensable element for vision and also presents difficulties when it comes to the diagnosis of possible alterations especially in wild bulls where direct contact is minimal. If we compare the histological results of the samples obtained in this work with other studies, we can identify the 10 layers of the retina completely intact as described in other studies. This indicates once again that the 
animals do not suffer alterations in the deepest areas of the eye, where it would be possible to find them mainly due to trauma.

\section{Conclusions}

From the results obtained in this study we can obtain the following conclusions:

1. There are no macroscopic lesions in the cornea of the bulls due to their activity, only $5 \%$ of the samples of fighting bulls and $10 \%$ of fire bull presented fluorescein positive lesions compatible with corneal ulcers. They will be associated probably with extrinsic causes to the celebration.

2. In bullring animals, despite prior veterinary recognition, there are small lesions in $10 \%$ of the animals, but these do not compromise the functionality of the animal.

3. In $100 \%$ of the samples, anatomical alterations of the internal structures of the eye of animals that have participated in both types of celebrations have not been detected by ultrasound.

4. In all the histologically analyzed samples, no alterations in the retinal structure of animals that have participated in both types of celebrations have been detected.

\section{References}

Barga Bensusán R. Taurología. Madrid: Espasa Calpe; 1989.

Mazón J, Albalate U. Querencias. Valencia: Diputación de Valencia; 2006.

Decreto 31/2015, de 6 de marzo, del Consell, por el que se aprueba el Reglamento de festejos taurinos tradicionales en la Comunitat Valenciana (bous al carrer).

Romero F. Taller de toros: La mirada del toro [Internet]. 2014 [citado 15 Abril 2018]. Disponible en: http://tallerdetoros.blogspot.com/2014/01/la-mirada-del-toro.html

Ocularis. La visión de los toros [Internet]. 2009 [citado 15 abril 2018]. Disponible en: https://ocularis.es/la-vision-de-los-toros/

Lo Sapio M, Bueno García JM (dir), Seva Alcaraz J (dir). Estudio sobre diferentes aspectos de la visión y la anatomía ocular del toro de lidia [tesis doctoral en Internet]. [Murcia]: Universidad de Murcia; 2015. [Citado 2 Abril 2018]. Disponible en: https://www.tdx.cat/handle/10803/365572

Sisson S. Anatomía de los animales domésticos. 5th ed. Masson; 1982. p. 257 - 277.

Junqueira L, Carneiro J. Basic histology. 6th ed. New York: McGraw-Hill; 2005. p. 460 - 463.

Sánchez L, Dellamea M, Hurtado J, Zunino M, Togni F, Sosa M. Ecografía y Doppler oftálmicos [Internet]. 2016 [citado 1 Mayo 2018]. Disponible en: https://oftalmologos.org.ar/oce/files/original/14417475fcd41de5e1082c1c145ad84c.pdf 
El Maghraby H, Nyland T, Bellhorn R. Ultrasonographic and biometric evaluation of sheep and cattle eyes. 1995 [citado 15 Mayo 2018];36(2):148-151. Disponible en: https://onlinelibrary.wiley.com/doi/abs/10.1111/j.1740-8261.1995.tb00236.x

Martínez-Ros P, Jiménez-Trigos E, López-Murcia M.M, Mayordomo Febrer A, Ortega Porcel J, Gómez Martín A, et al. Descripción de hallazgos oculares en toros embolados de la C. Valenciana. Estudio preliminar. Universidad CEU Cardenal Herrera; 2017.

González Alonso-Alegre E, Rodríguez Alvaro A. Membrana pupilar persistente [Internet]. 1997 [citado 20 Mayo 2018]. Disponible en:

https://ddd.uab.cat/pub/clivetpeqani/11307064v17n1/11307064v17n1p49.pdf

Gould D, McLellan G. BSAVA manual of canine and feline ophthalmology. 2nd ed. Quedgeley, Gloucester: British Small Animal Veterinary Association; 2014. p. 166.

Blasco Sánchez C, Cano Hurtado J, Martínez Pérez F, Saura Arnau H. Elementos y estructuras de barrera para festejos taurino tradicionales. [Internet]. 2017 [citado 13 Mayo 2018]. Disponible en: http://www.ctac.es/extranet/docs/bolsas_trabajo/MUN/inf-bous.pdf

Khaled A, Sinowatz F (dir). Glycohistochemical, Inmmunohistochemical and Electron Microscopic Examination of the Bovine Eyeball [tesis doctoral de Internet]. [Munich]: Universidad de Munich; 2003. [citado 20 de mayo de 2018]. Disponible en: http://citeseerx.ist.psu.edu/viewdoc/download?doi=10.1.1.232.6663\&rep=rep1\&type=pdf 